Journal of African Real Estate Research
Volume 6, Issue 1
Special Issue: Women in African Real Estate and Urban
Development Research

\title{
Improvements in Women's Access to Rural Farmland: The case of Ile-Ife, Nigeria
}

Augustina Chiwuzie ${ }^{1}$, Olusegun Adebayo Ogunba ${ }^{2}$ and Daniel Ibrahim Dabara ${ }^{3}$

${ }^{1}$ Department of Estate Management, Federal Polytechnic Ede, Nigeria.

${ }^{2}$ Department of Estate Management, Obafemi Awolowo University Ile-Ife, Nigeria.

${ }^{3}$ Department of Estate Management, University of Ibadan, Nigeria

To cite this article: Chiwuzie, A. Ogunba, O.A. \& Dabara, D.I. (2021). Improvement in Women's Access to Rural Farmland. Journal of African Real Estate Research, 6(1), pp.43-62. DOI: $10.15641 /$ jarer.v6i1.927.

\begin{abstract}
The study investigates women's access to rural farmlands in Ile-Ife, Nigeria, in the context of land availability, affordability, tenure security and ease of transaction. A qualitative research design was employed. Purposive and stratified sampling were utilised to obtain data from four key informants and 13 rural women farmers in Ajebandele village of Ile-Ife, Nigeria. Themes emerged from the responses through content analysis. Findings revealed that women's access to land has improved over the past four decades. The study concludes that despite the improvements, gender equality had not been fully achieved as rural women farmers lack tenure security.
\end{abstract}

Keywords: Land Allocation Process; Gender Inequality; Land Affordability; Poverty Alleviation; Tenure Security

\section{Introduction}

Land remains an essential resource for rural and urban people, particularly in the developing countries where the majority of the population depends on agriculture for their livelihoods (FAO, 2011). Lastarria-Cornhiel and Frais (2009) asserted that land represents a valuable cultural resource, a productive factor and capital asset, and those who control land rights have a certain amount of power over those who do not, especially in rural agrarian economies. In most of Africa, agricultural landholding is governed by customary land tenure systems. According to Pottier (2005), the land was considered a resource that all community members should have access to for

1 okagusta@yahoo.com 
subsistence. The land is seen as communally owned, and access to land within the customary sector is primarily based on membership in a particular landholding community, kinship or birth right. However, it has been widely acknowledged that women do not have equal land rights to men under customary land tenure. Kameri-Mbote (2005) observed that women only have secondary rights to land use, which can only be gained through their male relatives. As a result, women's access to land is dependent upon a relationship with a male donor and can be denied if the relative so wishes. According to Landesa (2012), this situation leaves women and the households they manage economically and socially vulnerable, thereby weakening women's ability to address their and their children's livelihood needs and agricultural productivity.

Gender disparity in access to productive resources such as agricultural land has continued to be an essential concern, particularly in African rural communities. The customary systems have established inequalities of access to land for women despite women's involvement in and invaluable contributions to agricultural productivity. Duncan (2004) posited that women represent the more significant population in the informal sector, particularly in the agriculture sector. According to Kagwanja (2008), women in Africa contribute $70 \%$ of food production, accounting for almost half of all farm labour and $80-90 \%$ of hoeing, food processing, storage and transport. Nevertheless, women lack adequate access to land and are not involved in significant decisions about allocation and land use, thus strangling women's productive role and contribution to national development (Kameri-Mbote, 2005). Access to land in this study is defined as the right to use a parcel of farmland for agricultural activities, decide the type of crops to be planted and enjoy the proceeds from the farmland. The strength of access to land rights influences the incentive for food production and investment in farmlands (Schurmann et al., 2020). Women's limited access to land affects their commitment to productivity-enhancing investments, especially in the type of crops they can grow. Fon (2011) noted that most Cameroon women wanted to create plantations but were frustrated by the gender disparity regarding access to land. According to Kuusaana et al. (2013), the International Fund for Agriculture Development (IFAD) observed that women generally do not plant fruit trees on the land they are farming. After all, they could quickly lose their land and all its accrued profits because they only hold a secondary right to the land. Landowners may develop interest in the land when the economic trees mature and find reasons to dispossess women of their right to the land.

Meanwhile, despite the increasing recognition that women are deprived in terms of access to land, a few pieces of evidence suggest that women's access to land is advancing. Woodman (1985) earlier suggested that women have easy access to land in rural areas and that what is required is the ability and resources to cultivate the land. Duncan and Brants (2004) noted that access to land rights in Ghana generally has evolved from the family right (e.g. acquired through allocation and inheritance) to the individual right (e.g. through gifts, lease and purchase). Also, Bugri (2008) observed that customary practices under the patrilineal land inheritance system in north- 
eastern Ghana are changing in favour of women and that access to land for livelihood needs is similar across genders. The reported progress in access to land rights can be attributed to the various land laws applicable in the study areas.

In Nigeria, the Land Use Act (LUA) of 1978 currently regulates land rights throughout the country. The Act vested the ownership of land rights in the state to ensure that all citizens (irrespective of gender) have equal access to land without impediment. The LUA provides for two systems of landholding: the customary (which applies at local government level) and statutory systems (applicable at the state level). Dabara et al. (2019) noted that under the customary system, land is predominantly accessed through inheritance where land ownership is handed from one generation to the next. Ile-Ife is a Yorubaland whose customary practice grants both men and women equal right to land. Also, "women are allowed to inherit land in the Yoruba custom (from their fathers, husbands, sons, or other family members)" (Ogbu \& Iruobe, 2018: p.36). However, the extent of women's access to land in the study area's customary land allocation process has not been adequately documented. Therefore, it is unclear whether an intervention is required to ensure equitable land allocation as provided by the LUA.

This study is particularly important as the growing scarcity of land, due to land commercialisation, diminishes women's access to land and erodes their agricultural productivity. This is especially true in a community such as Ajebandele village where most of the farming population is female. Hence, based on the suggestion that women's access to land has improved over time, this study sought to investigate women's access to farmlands in Ajebandele village of Ile-Ife, Nigeria. Of particular interest was women farmers' access to land in the context of land availability, land affordability, tenure security and ease of transaction with the intention of providing information that could enhance the land allocation process. The research questions that this study sought to answer include: What is the customary land allocation process in Ile-Ife? What is the extent of women's access to land in the context of land availability, land affordability, tenure security and ease of transaction? What are the factors influencing women's access to land in the study area? The remaining part of the paper is structured as follows: the next section presents a review of related literature; section three presents the methodology adopted for this study; section four presents results and discussions and the last section presents concluding remarks.

\section{Literature Review}

\subsection{Land Administration in Nigeria}

Before 1978, Nigeria operated customary land tenure systems. The applicable customary law varied from one locality to another. Nigeria is ethnically diverse, with more than 250 ethnic groups. Oni (2014) posited that Nigeria has an even greater number of customary laws than ethnic groups because variations in customary law exist within an ethnic area. Nonetheless, one common characteristic across the customary systems before 1978 is that land 
was communally owned with landholding units being the village, community, family and kinship. "Individual grantee is held to possess usufruct rights over land granted him" (Aluko \& Amidu, 2006, p.3). The customary land tenure systems were characterised by discrimination against women in land matters. Women did not have equal land rights with men, thus subjugating women's socio-economic and political rights under men's domination. Aluko and Amidu (2006) observed that while women depended on their male relations for land rights, men did not depend on their relationship with women for land rights. Also, women faced dispossession threats if marital conflicts led to divorce or separation and at the death of a husband.

To address gender inequality in land access, among other problems of the customary systems, the state intervened through the promulgation of LUA on March 29, 1978. The Act was enacted to eliminate gender discrimination, thereby making land easily accessible to every Nigerian (man or woman) and to unify the tenure system in the country to ensure equity and justice in land allocation and distribution. Section 1 of the LUA vests ownership in all land within the territory of each state in the Governor of the state and such land shall be held in trust and administered for the use and common benefit of all Nigerians. The Act provides for the state government to grant a statutory right of occupancy in urban lands. Likewise, the local government is to grant a customary right of occupancy to rural lands. In addition, the Act established special land use boards known as Land Use and Allocation Committees (LUAC) at the state level and Land Allocation Advisory Committees (LAAC) at the local government level. These new authorities advise the state and local governments, respectively, on land matters (Chapter L5 Laws of Federation of Nigeria, 2004).

\subsection{Women's Access to Rural Land}

Government land policies tend to either increase or decrease farmers' access to land rights (Keovilignavong and Suhardiman, 2020). In traditional African society, customs and traditions remain significant challenges in effecting policies that support women's access to land in rural communities (Almaz, 2007). A study that examined the implementation of customary land policies in Amhara, Ethiopia, revealed that policies supporting women's equal access to land did not bring required changes at the community level (Askale, 2005). Fon (2011) reported that rural women farmers in northwest Cameroon do have access to arable land through their families, but women do not control that arable land. The result, which found no association between access to and control of arable land, further suggested that women lack tenure security. Bonye and Kpieta (2012) found that most women do not own land in the Upper East Region of Ghana because women do not sacrifice to the land spirits, a requirement for owning land in the region. Furthermore, Aasoglenang et al. (2013) found that women lack ownership, control and full access to land in Ghana's Chansa community. That lack of access makes it difficult for women to cultivate cash crops and invest in other projects that could significantly enhance their socio-economic status. 
Adekola et al. (2013) revealed that men had more access to agricultural land than women in Ondo State, Nigeria. In addition, the majority of the men interviewed had the right to transfer land while none of the female respondents had such a right. Meanwhile, Odoemelam et al. (2014) reported that women in Abia State, Nigeria acquired land for cultivation mostly through matrilineal ties, other family ties, purchase and rental/borrowing but only occasionally through inheritance/gift. Most women were only allowed access to land to cultivate annual crops. Ajadi et al. (2015) investigated rural women farmers' access to productive resources among Nupe and Yoruba cultures in Nigeria. Results showed that men predominate in ownership of productive resources in Yoruba culture. Also, in both Nupe and Yoruba cultures, men decide almost all the farming activities.

In Ethiopia, Berhane and Miruts (2015) conducted a study premised on knowledge of the existing feudal and military system of land ownership, which restricts women's right to own land, and the feudal and military land ownership system's promise to eradicate the inequality in land rights. The findings revealed that the rural land administration system was not fully implemented because an equitable right to land was not recognised; registration, redistribution and land certification were done to favour men over women. Moyo (2017) equally found that a man's wife and a female child could not lay claim to the husband's and father's land, respectively, in the Makete District of Tanzania. Moyo reported that it is believed that the female child will soon be married off and will then be able to exercise her right to her husband's property. The study attributed the inequality practice in land ownership to the undeveloped state of Tanzania.

Further studies have explored women's tenure security and land rights. Prindex (2019) analysed the perceptions of tenure insecurity among women in 33 countries, including Benin, Kenya, Morocco and Nigeria in Africa. The primary indicator of tenure insecurity was the likelihood of losing the right to use a property against a respondent's will. The findings showed that gender differences exist in specific country contexts. Benin displayed a $6 \%$ difference in tenure insecurity; the highest among countries where insecurity rates were higher for women than for men. On the other hand, Nigeria displayed a $2 \%$ disparity between men's and women's perceptions of tenure insecurity. Ghebru and Lambrecht (2017) assessed tenure security based on the risk of losing land in the event of leaving it empty for several months. The findings revealed a strong association between gender and perceived tenure security in Ghana; male heads of household were generally more secure than female heads of household. In Nigeria, Odoemelam et al. (2014) reported that about $13 \%$ of women in their study were not allowed to retain access to land after a long fallow. Dabara et al. (2017) posited that tenure insecurity contributes to stagnating economic development among landholders.

Women seeking to obtain access to land may find the transaction is difficult. Moyo (2007) highlighted the constraints faced by women in applying for land, including bureaucratic constraints; gender biases within the selection structures, which are comprised mainly of men; lack of information on the 
process; and low mobilisation of women's activist organisations around the issue of applications for land ownership. Enete and Amusa (2010) revealed that women in most farming societies face attitudinal barriers such as misconceptions that women farmers do not have basic farming knowledge and low self-confidence in making individual farming decisions. The International Organization for Migration (IOM) (2016) reported some of the challenges women face in accessing land. These include society's distrust in women's land ownership, perception about property misuse by women and harassment when women engage in land-related transactions, including buying and selling.

Researchers have suggested that several factors influence women's access to land in different study areas. Agana (2012) and Kuusaana et al. (2013) identified factors hindering women's access to land in Ghana to include common beliefs about ownership of land, customary rules on inheritance, the taboo forbidding women from performing sacrifices to ancestors, financial constraints and the high illiteracy rate among women. Dowuona-Hammond (2003) earlier posited that women's lack of access to land in Ghana is linked to women's higher poverty levels and other burdens. Chigbu et al. (2019) revealed other factors including marital status, health status, economic status and socio-political status. There were also cases where women contribute to their lack of access to land through 'their actions or inactions' (Chigbu, (2019).

Existing studies have shown that women generally have problems accessing land in the African context. Specifically, customary laws on access to land and inheritance do not support women's causes. While women were not entitled to land rights in some customary practices, others grant women farmers access to secondary rights in farmlands through their families. Therefore, this study intends to add to the discussions on women's land rights in Nigeria by investigating the extent to which the provisions of the Nigerian LUA advanced women's equal access to farmland in Ajebandele village, IleIfe, Nigeria.

\section{Methodology}

The study area is Ajebandele village, a rural settlement in Ile-Ife, Osun State, Nigeria. It has a population of about 600 (Deji \& Solomon, 2020). The population of the community is comprised of different ethnic groups, most of whom are the Yoruba-speaking people. The residents are predominantly farmers growing cassava, yams, cocoa and maize at subsistence level. Ajebandele has vast arable land; the soil has a medium to fine texture and is mostly well-drained. The village is located within the tropical rain forest. The climate is characterised by two seasons; the wet season (April to October) and the dry season (November to March). Ajebandele village shares similar characteristics with other villages in southwest Nigeria. Villages in Yorubaland practice a customary land tenure system wherein the right to land ownership is held by a range of groups from the community, kinship or family. Ajebandele is a typical agrarian community with a higher number of 
women farmers compared to men in the ratio of about three women to two men. According to the Baale (the traditional head) of the village, Ajebandele contains six communities with an average of 60 women in each out of the total village population of 600 .

The study employed a qualitative research design. Data were obtained through fieldwork and consisted of a key informant interview with community leaders and a structured questionnaire and interview with rural women farmers. While the key informants were purposively selected, women farmers were selected using stratified sampling. First, the women were grouped into the six communities that made up the village. Next, women were randomly selected from each community. The sample's determination for this study followed the recommendations in Creswell (1998) that in qualitative studies, the required number of participants depends on when a point of saturation is reached. Thus, both groups of respondents were continuously interviewed until a point of saturation was reached. In all, saturation was reached with four key informant interviews and 13 women farmers (two women from each of the five communities and three women from the one remaining community). The $13^{\text {th }}$ woman was required to achieve saturation. The key informants consisted of four of the six community heads in the village. They played a significant role in the allocation of customary land and were able to provide detailed and reliable information on the subject matter. On the other hand, the women farmers were chosen because they would be able to provide information on how they acquire land.

Data were gathered on the land allocation process operating in the study area in 2019 relative to the practice before 1978. Additional data were collected to ascertain the extent of rural women's access to land as well as factors responsible for women's inaccessibility to land. All interviews were conducted between October and November 2019 in the local language (Yoruba) through a structured interview guide. The research questions in the interview guide were the same for the two groups. All the interviews followed the same outline, starting with questions about the respondents' socioeconomic background, followed by research questions. An audio recorder was used to document the respondents' opinion on each of the research questions. The recorded responses were translated and transcribed into written form. On completion of the transcription, several themes emerged from the responses through content analysis.

\section{Discussion of Findings}

This section presents and interprets the findings on women's access to rural farmland in Ajebandele village, Ile-Ife, Nigeria, in 2019. The themes that arose through content analysis are discussed and organised by the research questions. Some of the responses are quoted in-text to collaborate the discussion of the findings in this study. The socio-economic characteristics of the women farmers are presented in Table 1 below. 
Table 1: Demographic Characteristics of Rural Women Respondents

Source: Field Survey, 2019

\begin{tabular}{|l|c|}
\hline Variables & Percentage (n=13) \\
\hline Occupation & $100 \%$ \\
\hline Farmers & \\
\hline Family Structure & $38.46 \%$ \\
\hline Monogamous & $61.54 \%$ \\
\hline Polygamous \\
\hline Marital Status \\
\hline Married & $64.70 \%$ \\
\hline Widow & $23.53 \%$ \\
\hline Single & $11.76 \%$ \\
\hline Ages & \\
\hline $25-31$ & $7.69 \%$ \\
\hline $32-38$ & $15.39 \%$ \\
\hline $39-45$ & $53.85 \%$ \\
\hline 46 and older & $23.07 \%$ \\
\hline Educational Qualifications \\
\hline Primary level \\
\hline Secondary level & $23.08 \%$ \\
\hline Tertiary level & $46.15 \%$ \\
\hline
\end{tabular}

The women respondents' demographic distribution in Table 1 shows that the study includes women from different age groups, marital statuses, family structures and educational qualifications. The majority of the respondents were married. Eight of the 13 women interviewed were in a polygamous family. This could explain the higher population of women in the village as compared to their male partners. Just over one-half of the women surveyed are age 39 to 45 . Ten women farmers had at least a secondary education.

\subsection{Customary Land Allocation Process}

This subsection provides answers to the first research question (What is the customary land allocation process in Ile-Ife in 2019 after the LUA?). Customary land is that which is owned by indigenous communities and administered following their customs. Both the key informants and women farmers gave insights into the customary land allocation process practiced in the study area. The responses received from the two groups of respondents are discussed below.

\subsubsection{Key Informant Interviews}

When asked about the land allocation process, the key informants stated that there are three classifications of land in the study area. The classification is based on management, control and the way the proceeds from the land are shared. The three classes of land identified are community land, family land and palace land. In a key informant's words: 
"We have three classes of land in the village: the family land, owned and managed by the family member; the community land is managed and controlled by the Baale of the village and Chief Lukosi of Ife while the palace controls the palace land. The proceeds from palace land are divided into three portions. One portion for the labourer, another for the Lukosi compound and the other for the palace."

(Community leader 1, 2019)

The key informants further reported that the allocation of land in the village was the community heads' sole duty. A committee currently handles land allocation to anybody (irrespective of their gender) interested in farming activities within the village. Individuals seeking land must provide a guarantor. Land allocated to individuals is documented. The allocatees bring wine to the elders for blessing and pay a tribute (a portion of the farmland's proceeds; the tribute is a kind of commitment made to the property owner regarding the leased land, and the payment is typically made yearly or subject to the agreement between the parties). The key informants acknowledged that the process of land allocation had changed, noting that in the olden days (the period before the promulgation of the LUA), land was acquired through first settlement. Land was also given out liberally to people without records or any payment. These practices resulted in land disputes.

"We selected some elders that have a vast knowledge about the land in the village to see to the administration of land to those that requested for land. Such land is leased out and not sold. The lessee will be expected to pay tribute on the farmland. In the olden days, our fathers gave out land freely to the people, and this resulted in some of our land falling into the wrong hands."

(Community leader 3, 2019)

Furthermore, the key informants emphasised that there have been changes regarding women's access to land. It was reported that to an extent, there are no restrictions on women's access to land ownership in the village. Both women and men now have equal access to land rights. However, the key informants noted that women still find it challenging to inherit land owned by their husbands.

"Women were not entitled to inherit a property in the olden days. Women were denied the right to inheritance of their father's property in the olden days. Civilisation and several awareness programs have caused changes in access to land and women can claim their right to the deceased father's property just as the men but it is difficult to get land in one's husband house."

(Community leader 1, 2019)

\subsubsection{Women Farmer's Interviews}

Women farmers were interviewed about how they acquired land in recent times relative to before the LUA. Some of the responses revealed that women now acquire land through purchase, gift, lease and inheritance from one's father. The women further confirmed that women now inherit land from their fathers, unlike in the past, when women were considered inheritable property. 
"My husband was invited to this village by his friend who gave him farmland, which we are cultivating for both food and cash crops. We are not paying any tribute since the land was given freely. I was given farmland by my husband, the proceeds of which are being used to manage our home. I also purchased a plot of land from an owner with agreement on the amount to pay."

(Woman 2, 2019)

"I inherited it from my father. Women were restricted from inheritance in the olden days as they (women) formed part of the inheritable property."

(Woman 8, 2019)

From the above responses, it can be deduced that the present-day land allocation process has improved compared to the practices before the LUA of 1978. The community introduced a measure to facilitate land allocation by instituting a committee that oversees land allocation and is accountable to the community leaders. The requirements for acquiring farmland through community allocation are that the recipient must be a farmer and provide a guarantor who must be a well-known person in the village. In the past, no land allocation records were kept. However, now details of land allocation are appropriately documented, implying that more attention is being given to land, possibly due to the increasing recognition of the land's value. Most importantly, there is no gender discrimination in access to land; the restriction placed on women regarding access to land before the LUA of 1978 has been removed, suggesting that women's access to land has improved in alignment with the assertion in Bugri (2008).

\subsection{Rural Women's Access to Land}

In this section, the extent of rural women's access to land in Ajebandele village in the context of land availability, land affordability, land tenure security and ease of transaction is explored. The findings are discussed under the subheadings for each context.

\subsubsection{Land Availability}

Land availability is essential for access to land. The responses from both groups of interviewees revealed that farmland is made available to women. Six themes as to how land is made available are land clearance, inheritance, purchase, lease, cultivation grant and a gift from friends.

The findings in Table 2, show that women have multiple ways to acquire land rights in the study area. This suggests that the LUA has advanced women's access to land in the context of land availability. Available farmland within the community or family holdings is accessible to both women and men farmers in line with the observation of Aluko and Amidu (2006). 
Table 2: Ways Women Acquire Rights to Rural Farmland in Ile Ife

\begin{tabular}{|l|l|}
\hline Theme & Description of Responses \\
\hline Land clearance & $\begin{array}{l}\text { A system in which one could acquire an interest in farmland (for } \\
\text { an agreed period) in exchange for a particular activity (field } \\
\text { clearance). }\end{array}$ \\
\hline Inheritance & $\begin{array}{l}\text { The family land is transferred to the deceased's family lineage or } \\
\text { heirs. Individual's family land is inherited in equal proportion by } \\
\text { the deceased's children irrespective of gender. }\end{array}$ \\
\hline Lurchase & $\begin{array}{l}\text { An outright transfer of an interest in land for cash payment. } \\
\text { Presently, family land is sold subject to the family members' } \\
\text { consent as represented by the principal or head in a polygamous } \\
\text { family. }\end{array}$ \\
\hline Cultivation grant & $\begin{array}{l}\text { The transfer of leasehold interest in land to another person in } \\
\text { consideration for cash or products from the farmland (Tribute) for } \\
\text { an agreed period. The terms of such a lease are usually } \\
\text { documented. }\end{array}$ \\
\hline Gift & $\begin{array}{l}\text { Women were granted the right to cultivate the land by their } \\
\text { husband, friends or family. Cultivation grant was the most } \\
\text { accessible interest to rural women farmers. }\end{array}$ \\
\hline & $\begin{array}{l}\text { Allocation of land by friends and relatives involves transferring } \\
\text { an interest in farmland to a person without consideration in cash } \\
\text { or kind. }\end{array}$ \\
\hline
\end{tabular}

In this study, six of the interviewed women farmers had acquired land through inheritance. This finding agrees with Dabara et al.'s (2019) assertion that land inheritance remains the predominant means of acquiring land in agrarian settlements where land ownership is handed from one generation to the next. Land availability through inheritance was accessible to most women except some who were threatened or denied the right to land by greedy siblings or by members of her husband's family, especially a childless woman. Both the key informants and women farmers agreed that community land was not inherited but instead reallocated to community members. The other ways of acquiring rights were less common among the respondents. Two women accessed land through purchase, whereas three women accessed farmland through a lease. Only one woman gained access to land through allocation by a friend and one through a cultivation grant.

Access to land through land clearance was no longer in practice in the study area. This could be attributed to the commercialisation and increased land value in most peri-urban areas, including rural communities. Hence, field clearance is considered inadequate to be exchanged for an interest in the land.

\subsubsection{Land Affordability}

This section addresses the cost of acquiring land; it also compares the ability of a woman (relative to a man) to acquire land through purchase, lease or gift. The means of acquiring land is synonymous to what is given in exchange (consideration) for the right to land. Four themes arose from the responses: affordability of purchased land, affordability of tribute on leased land, 
affordability of wine as consideration for land allocation and affordability of land acquired through gift and cultivation grant. Consideration given for land rights could be cash or in kind depending on the land's ownership structure.

Land acquisition through purchase was unaffordable to women as well as men in Ajebandele village. Although the purchase price is the same for both female and male farmers, women felt the price could be more unaffordable for them as they do not have the same purchasing power as the men.

Land acquisition through gift and cultivation grant was affordable to both men and women farmers because such land is given out freely. Land allocation by the community was affordable to women since the requirement, such as wine, was something within reach of women as well as men. Conversely, through a lease, land acquisition was considered affordable by some women, while others maintained there were instances where leasing was unaffordable to women farmers due to an overwhelming tribute. Tribute was considered affordable where it is based on the farm proceeds, and the lessee farmer is expected to make the payment after harvesting of farm produce. However, two women reported instances where the expected tribute was so much that the lessee farmer would be left worse off at the end of the farming activity. The women insisted that tribute on leased land cannot be said to be affordable in such a situation.

\subsubsection{Land Tenure Security}

Land tenure security is the third component used to judge women's access to land in this study. This section addresses the extent to which women's rights to land is secured. Specifically, it explores the basis upon which women's rights to land could be withdrawn relative to men. Four themes emerged from the responses: revocation for public use, revocation for socio-cultural and family issues, revocation for legal issues, and revocation for economic issues as defined in Table 3.

Table 3: The Basis for Revocation of Women's Right to Land

\begin{tabular}{|l|l|}
\hline Theme & Description of Responses \\
\hline Revocation for public use & $\begin{array}{l}\text { Rights to farmland revoked for overriding public purposes } \\
\text { such as community or government use. }\end{array}$ \\
\hline $\begin{array}{l}\text { Revocation for socio- } \\
\text { cultural and family issues }\end{array}$ & $\begin{array}{l}\text { Divorce, misconduct, intentional act, family crisis, } \\
\text { violence, death or land dispute results in the revocation of } \\
\text { land rights. }\end{array}$ \\
\hline Revocation for legal issues & $\begin{array}{l}\text { Breach of agreement, lease expiration and illegal sales are } \\
\text { the basis upon which rights to farmleand can be revoked. }\end{array}$ \\
\hline $\begin{array}{l}\text { Revocation for economic } \\
\text { issues }\end{array}$ & $\begin{array}{l}\text { Improper management and withdrawal for personal use } \\
\text { results in the revocation of land rights. }\end{array}$ \\
\hline
\end{tabular}

Evidence from the responses suggests both men's and women's rights to farmland could be revoked without any form of discrimination for public use, lease expiration, breach of the agreement and invalid sale. Similarly, 
misconduct, an intentional act, family crisis or land dispute, improper management and withdrawal for personal use can result in revocation of men's and women's rights.

However, only women's rights to farmland can be revoked at divorce, separation and death of the spouse. This finding agrees with the position in Aluko and Amidu (2006) and further supports the argument in this paper regarding the disparity in land rights across gender. At the death of a husband, the family members often displaced the wife (most commonly, the childless ones) from her deceased husband's property. This resulted in the affected women losing access to farmland, thus, rendering such women economically unproductive.

In addition, two of the women interviewed reported instances where women were displaced from their father's property by their greedy siblings. Furthermore, some women access land through cultivation grant from family and friends without cash payment. This way, the owner of the land retained the primary right to the land. This undermines women's security of tenure. Such land can be withdrawn at any time by the owner. Most women farmers merely use the farmland under controlled conditions and are unable to cultivate the land without continual interference. Hence, it can be deduced that rural women farmers in Ajebandele lack adequate security of tenure. This finding is congruent with the conclusions of Ghebru and Lambrecht (2017) in Ghana. Inadequate tenure security can have socio-economic implications for women as posited in Dabara et al. (2017).

\subsubsection{Ease of Transaction}

This section addresses the fourth component of accessibility, which refers to the challenges women face before acquiring land in Ajebandele customary practice. A total of five themes emerged from the responses: sexual harassment, doubt of women's competence, the requirement for a guarantor, lack of investment information and delays due to conditionality.

The responses reveal that harassment by the community leaders was one of the challenges women face while searching for farmland for cultivation. However, some women in this study stated that they were not harassed before they acquired land rights. This might be connected to the fact that most of the respondents (six women) acquired land through inheritance of their deceased father's property. Additionally, a lack of confidence in women's capability to undertake farming activities delayed their access to farmland. Landowners (in the case of family land) and the community leaders (in the case of community land) tend to doubt women's competency to farm. Such doubts led to some women being denied or delayed land allocation. This finding agrees with the assertions in Enete and Amusa (2010) that women in most farming societies face attitudinal barriers and can be attributed to societal misconceptions about women farmers. Furthermore, a woman seeking land for cultivation was asked to provide a guarantor who may or may not be her husband before land can be allocated to her. The requirement for a guarantor delayed women's 
access to farmland. There were cases where some husbands frown at their wives having private farmland and tend to restrain other men from standing as a guarantor to such wives, thus, delaying or hindering their access to land.

Access to information is vital to accessing land rights; the absence of information about land offered for sale, including the original owner of the land and the land's fertility delays the sale of such land. It was reported that women are less informed about land-related matters because they are confined within the house. Thus, lack of information acts as a significant challenge to women's access to land.

Some women acquire land based on certain conditions such as giving their daughter in marriage to the landowner or the landowner's son. Such an acquisition can be delayed if the party did not meet the condition. This challenge was reported to affect both men and women that acquire land in such a manner. One of the women interviewed said she and her husband accessed the farmland they are cultivating on the condition that their daughter will be married to the landowner's son and the wife was made to ensure the party get married before they were given the land.

\subsection{Factors Influencing Women's Access to Land}

This section addresses the factors that influence women's access to land in the study area. The themes that emerged from the key informants and women farmers' responses are shown in Table 4 and discussed below.

Table 4: Factors that Restrict Women's Access to Land

\begin{tabular}{|l|l|}
\hline Themes & Description of Responses \\
\hline Custom and tradition & $\begin{array}{l}\text { Some cultural beliefs, land tenure problem and limited } \\
\text { land restrict women's access to land in the study area. }\end{array}$ \\
\hline $\begin{array}{l}\text { Educational } \\
\text { status/awareness }\end{array}$ & $\begin{array}{l}\text { Illiteracy, ignorance and lack of necessary information } \\
\text { were noted to affect women's access to land. }\end{array}$ \\
\hline Unavailability of finance & $\begin{array}{l}\text { The limiting factor to purchasing land is inaccessibility } \\
\text { to finance, especially for a woman. Women were } \\
\text { considered to be working at a lower level and lower pay } \\
\text { compared to men. }\end{array}$ \\
\hline Personal factors & $\begin{array}{l}\text { Factors that have to do with the woman herself including } \\
\text { woman's actions or inactions, health status, } \\
\text { incompetency, lack of interest or passion for other } \\
\text { sectors such as trading, skill acquisition or paid } \\
\text { employment affect women's access to land. }\end{array}$ \\
\hline Socio-economic factors & $\begin{array}{l}\text { Family crisis, family structure, marital status and } \\
\text { husband influence impact on women's access to land. }\end{array}$ \\
\hline Religion & $\begin{array}{l}\text { Specific religious belief restricts women's access to land } \\
\text { rights. }\end{array}$ \\
\hline
\end{tabular}

In line with Moyo's (2017) work in Tanzania and Chigbu et al.'s (2019) in sub-Saharan Africa, the responses show that custom and tradition and religion influence women's access to land. The interviewees explained that custom 
and tradition significantly influence women's access to land. A substantial number of the villagers are members of the Idoma and Igala tribes in which only the men lease and work on the farmlands. Because the Idoma and Igala tribes' customs do not permit the women to engage in farming activities, their access to farmland is restricted. Religious status was also a basis for gender discrimination in land access; the Niqobait (veiled Alhaja) of the village were restricted from undertaking farming activities and, therefore, had no access to farmland.

The theme of education and awareness includes illiteracy, ignorance and lack of necessary information as influences on women's access to land. Both the key informants and women farmers indicated that women were unaware of their right to land as provided in section 42 of the Nigerian constitution; hence, they could not claim their land rights. "Women...started challenging community traditions on land acquisition as they get aware of their rights" (Almaz, 2007, p.84). Thus, knowledge about land rights is critical in breaking custom and traditional impediments to women's access to land. Also, the land market is unique in the secrecy of information in the market. This problem was exemplified by reports that land grabbers duped some women through fraudulent sales due to unavailability of firsthand information.

One limiting factor to purchasing land is the lack of access to financing, especially for women. Women were considered to be working at a lower level and lower pay compared to men. All the interviewees agreed that women's lower pay, coupled with the burden of home-keeping have a negative impact on their income flow and access to adequate financing. This finding is congruent with Dowuona-Hammond's (2003) suggestion that women's lack of access to land in Ghana is linked with women's higher level of poverty and other burdens.

Characteristics of the female farmer we label as personal factors, such as health status, incompetency, lack of interest or passion for other sectors such as trading, skill acquisition or paid employment were cited by respondents as contributors to lack of access to land. All the respondents also identified women's 'actions and inactions' as restricting women's access to land in line with the submission in Chigbu, (2019). These factors hinder women in the study area from taking steps toward acquiring land even with the knowledge of land value. Furthermore, the respondents identified socio-economic factors as a theme contributing to lack of access to land. Family crisis is a regular happening amidst greedy siblings who oppose women's access to land based on the belief "she will be getting married to a man, from whom she will get land" (Woman 2, 2019). The interviewees confirmed that a polygamous family structure entailed that wives would work on their husbands' farmland, which tends to restrict women's access to land. Some of the women farmers interviewed argued that some husbands were capable of frustrating their wives' desire to acquire land even through allocation or gift. This, the interviewees said, was to ensure that the wives continued to work on the husband's farmland even amid discriminatory allocation of farmlands among wives in a polygamous family setting. 


\section{Conclusion}

This study investigated women's access to rural farmlands in Ajebandele village of Ile-Ife, Nigeria, in the context of land availability, land affordability, tenure security and ease of transaction with the intent of establishing the extent to which provisions of the Nigerian LUA advanced women's equal access to farmland in the study area. Findings from the study revealed an appreciable difference in the present-day land allocation process compared to the practices before the LUA. This is reflected by the local committee that is instituted to facilitate land allocation in the village. Farmland within the community or family holdings is legally accessible to both men and women through inheritance, purchase, lease, cultivation grant, gift and allocation. Additionally, land acquisition through gift or cultivation grant is affordable to women farmers. However, access to land through purchase and lease can be unaffordable to women farmers due to the cost of purchasing land and overwhelming tribute. Furthermore, the women interviewed lacked security in their right to farmland. Women are dispossessed of their right to farmland at divorce, separation and death of the husband.

The customary process of land allocation in Ajebandele village, Ile-Ife, Nigeria has been refined over the past four decades to support women and in theory, provides equal access to land for men and women in terms of land availability and affordability. It also ensures that the process of accessing land is not burdensome. Notwithstanding these improvements, the Nigerian LUA provisions have not wholly attained women's equal access to farmland in Ajebandele village, Ile-Ife, Nigeria. Rural women farmers still lack access to land in the context of tenure security. Thus, gender differentials still exist in the security of tenure in land in the study area.

Insecure access to land remains one of the major elements that creates and sustains poverty among women in farming communities of Sub-Saharan Africa; where customary laws and traditional practices have instituted gender inequalities in access to secure land rights. Other African countries such as Ghana, Cameroon, Ethiopia and Tanzania have similar customs and traditions that impact women's secure land rights and could benefit from this study's results and recommendations. Hence, policymakers should pay attention to gender biases concerning women's tenure security to guarantee equal access to land. This can be achieved by restructuring the customary land administration in a gender-sensitive way to strengthen women's secure land rights and ensure equal benefits from policy results. Even though socioeconomic concerns play a role in women's insecure access to land, custom and tradition, principally, influence the realisation of gender equality in land rights. There is, therefore, a need for change in the practices that introduce women's tenure insecurity to bring about greater gender justice in women's land rights. Governments and society should devise plans to address women's insecure land rights through advocacy and awareness campaigns to revolutionise the community's mind-sets and practices. 
This study's limitation is that it was carried out in a village and during the rainy season; some areas were inaccessible due to the poor state of the road network in the village. Thus, only a small number of farmers were interviewed, but the researchers believe that their response was generally applicable in the village. Further research involving more villages and respondents is also recommended to bring forth comprehensive rural women's land right issues for policy and implementation.

\section{References}

Aasoglenang, A.T., Kanlisi, S.K., Naab, F.X., Dery, I., Maabesog, R., Maabier, E.B. \& Naa-Obmuo, P. (2013). Land access and poverty reduction among women in Chansa in the North-western Region of Ghana, International Journal of Development and Sustainability, 2(2), pp.1580-1596.

Adekola, A.G., Adereti, F.O., Koledoye, G.F. \& Owombo, P.T. (2013). Gender discrimination in agricultural land access: implications for food security in Ondo State, Nigeria, Journal of Development and Agricultural Economics 5(2), pp.49-56. DOI: 10.5897/JDAE12.048.

Agana, C. (2012). Women's land rights and access to credit in a predominantly patrilineal system of inheritance: a case study of the Frafra traditional area, Upper East region. M.Phil Thesis, Kwame Nkrumah University of Science and Technology, Ghana.

Ajadi, A.A., Oladele, O.I., Ikegami, K. \& Tsuruta, T. (2015). Rural women's farmers access to productive resources: the moderating effect of culture among Nupe and Yoruba in Nigeria. Agriculture and Food Security, 4(26), pp.1-9. DOI 10.1186/s40066-015-0048-y.

Almaz, W. (2007). Women's access to and control over land in the current land administration system in two rural kebeles in Ada' a Woreda of Oromia region. MSc Thesis, Addis Ababa University.

Aluko, B.T. \& Amidu, A. (2006). Women and land rights reforms in Nigeria. Proceedings of the 5th FIG Regional Conference, Promoting Land Administration and Good Governance. Accra, Ghana.

Askale, T. (2005). Land registration and women's land rights in Amhara Region, Ethiopia, securing land rights in Africa. London: International Institute for Environment and Development.

Berhane, T. \& Miruts, G. (2015). Rural women land use right in Tigray regional state: the case of Kafta Humra Woreda, Journal of Culture, Society and Development, 10, pp.47-61.

Bonye, S.Z. \& Kpieta, A. (2012). Women, ownership and access to land in the Upper East Region of Ghana, International Journal of Humanities and Social Science, 2(9), pp.66-74.

Bugri, J.T. (2008). Gender issues in Africa land tenure: findings from a study of North-East Ghana. Journal of the Ghana Institution of Surveyors, 1(1), pp.21-35.

Chigbu, U.E. (2019). Masculinity, men and patriarchal issues aside: how do women's actions impede women's access to land? Matters arising 
from a peri-rural community in Nigeria. Land Use Policy, 81, pp.3948.

Chigbu, U.E., Gaynor, P. \& Walter D. (2019). Differentiations in women's land tenure experiences: implications for women's land access and tenure security in Sub-Sahara Africa. Land, 8(2), pp.1-21.

Creswell, J.W. (1998). Qualitative inquiry and research design: choosing among five traditions. Thousand Oaks. CA: Sage publications.

Dabara, I.D., Ankeli, I.A., Akinjogbin, O.I., Omotehinshe, J.O. \& Omoyosi, G.A. (2017). A study of the legislations affecting property rights in Gombe State, Nigeria, Humanities and Social Sciences Review, 6 (2), pp.1-8.

Dabara, D.I., Lawal, O.K., Chiwuzie, A., Omotehinshe, O.J. \& Soladoye, J.O. (2019). Land tenure systems and agricultural productivity in Gombe, Nigeria. Madridge Journal of Agriculture and Environmental Science, 1(2), pp.51-59.

Deji, S.A. \& Solomon, O.O. (2020). A cross-sectional study on household food security in rural villages of Osun State Nigeria. The Nigerian Stethoscope, 2(1), pp.8-12.

Dowuona-Hammond, C. (2003). Report on state land management and its impact on women and the poor in Ghana, GTZ Legal Pluralism and Gender Project (Land Law Focal Area), Accra, Ghana.

Duncan, A.B. (2004). Women in Agriculture in Ghana. 2nd edition, Friedrich Ebert Foundation, Accra.

Duncan, B.A. \& Brants, C. (2004). Access to and control over land from a gender perspective - a study conducted in the Volta Region of Ghana. Accra, Food and Agriculture Organization of the United Nations. [Online]. Available at: http://www.fao.org/3/ae501e/ae501e00.htm. Accessed: $6^{\text {th }}$ June, 2020.

Enete, A.A. \& Amusa, T.A. (2010). Determinants of women's contribution to farming decisions in cocoa-based agroforestry households of Ekiti State, Nigeria, Field Actions Science Reports. [Online]. Available at: http://journals.openedition.org/factsreports/396. Accessed: $23^{\text {rd }}$ March, 2020.

FAO. (2011). The State of Food and Agriculture 2010-2011: Women in Agriculture - Closing the Gender Gap for Development, 23, Food and Agriculture Organisation of the United Nations. [Online]. Available at: http://www.fao.org/publications/sofa/2010-11/en/. Accessed: $22^{\text {nd }}$ April, 2020.

Federal Government of Nigeria. (2004). Land Use Act 1978. Chapter L5 Laws of the Federation of Nigeria, 2004.

Fon, D.E. (2011). Access to arable land by rural women in Cameroon. Tropicultura, 29(2), pp.65-69.

Ghebru, H. \& Lambrecht, I. (2017). Drivers of perceived land tenure (in)security: Empirical evidence from Ghana. Land Use Policy, 66, pp.293-303.

IOM. (2016). Barriers to women's land and property access and ownership in Nepal. Kathmandu, Nepal: International Organization for Migration. 
Kagwanja, J. (2008). African Women Struggle to Secure Land Rights. Africa Renewal, 22(1), p.10.

Kameri-Mbote, P. (2005). The Land has its owners! Gender issues in land tenure under customary Law. UNDP-International Land Coalition Workshop: Land Rights for African Development: From Knowledge to Action, Nairobi, October 31 - November 3. [Online]. Available at: http://www.undp.org/drylands/lt-workshop-11-05.htm. Accessed: $23^{\text {rd }}$ July, 2019.

Keovilignavong, O. \& Suhardiman, D. (2020) Linking land tenure security with food security: Unpacking farm households' perceptions and strategies in the rural uplands of Laos, Land Use Policy, 90, pp.1-11. DOI.org/10.1016/j.landusepol.2019.104260.

Kuusaana, E.D., Kidido, J.K. \& Halidu-Adam, E. (2013). Customary land ownership and gender disparity evidence from the Wa municipality of Ghana, GJDS, 10(1-2), pp.64-80.

Landesa. (2012). Women's secure rights to land: benefits, barriers and best practices. Issue Brief. Seattle: Landesa.

Moyo, K.J. (2017). Women's Access to Land in Tanzania: the case of the Makete district. PhD Thesis, Royal Institute of Technology (KTH), Stockholm. [Online]. Available at:

http://urn.kb.se/resolve?urn=urn:nbn:se:kth:diva-202913. Accessed: $18^{\text {th }}$ May, 2020.

Moyo, S. (2007). Land reform under structural adjustment in Zimbabwe. Stockholm: Elanders.

Odoemelam, L.E., Alamba, C. \& Lekan-Akomolafe, C.N. (2014). Evaluation of women access and rights to land and its implications on rural household food security in selected rural communities, Abia State, Nigeria. Discourse journal Agriculture and Food Sciences, 2(8), pp.235-241.

Ogbu, C.P. \& Iruobe, P. (2018). Comparison of formal and informal land administration systems in Lagos State: the case of Epe LGA, Journal of African Real Estate Research, 3(2), pp.18-43. DOI: 10.15641/jarer.v0i0.567.

Oni, B.A. (2014). Discriminatory property inheritance rights under the Yoruba and Igbo customary law in Nigeria: the need for reforms. IOSR Journal of Humanities and Social Science (IOSR-JHSS) 19(2), pp. 30-43.

Pottier, J. (2005). Customary land tenure in Sub-Saharan Africa today: meanings and contexts. In Huggins, C. \& Clover, J. (Eds), From the Ground Up: Land Rights, Conflict and Peace in Sub-Saharan Africa. Nairobi/Pretoria: Acts Press/Institute for Security Studies. pp. 55-75.

Prindex. (2019.) Women's perceptions of tenure security: evidence from 33 countries. London: Overseas Development Institute.

Schurmanna, A., Kleemanna, J., Fursta, C. \& Teucher, M. (2020) Assessing the relationship between land tenure issues and land cover changes around the Arabuko Sokoke Forest in Kenya, Land Use Policy 95, pp.1-13. DOI.org/10.1016/j.landusepol.2020.104625.

Woodman, G. (1985). Customary land, state courts and the notion of institutionalisation of norms in Ghana and Nigeria. In Allot, A. \& 
Journal of African Real Estate Research

Special Issue: Women in African Real Estate and Urban Development

Research

Woodman G.R (Eds), People's Law and the State. Dordecht: Foris Publications. pp.143-63.

\section{Acknowledgement}

The authors wish to acknowledge Professor Stephanie Rozelle Yates for her mentorship. Her support, kindness and advice were invaluable in making this research work more robust. 